\title{
Project NPV, Positive Externalities, Social Cost-Benefit Analysis- The Kansas City Light Rail Project
}

Sudhakar Raju, Rockhurst University

\begin{abstract}
The Heartland Light Rail project represents Kansas City's biggest infrastructural investment in decades. The ballot initiative for the light rail project was voted down three times until it was finally approved in November 2006. Using best estimates of construction costs, operating expenses and federal funding, I estimate the net present value (NPV) of the project to be negative $\$ 343$ million. From a standard NPV perspective the Kansas City light rail transit (LRT) system is unlikely to break even. However, if the negative externalities of auto travel and the positive externalities associated with light rail are properly accounted for in a comprehensive social costbenefit framework, investment in the Kansas City LRT system becomes an increasingly feasible option.
\end{abstract}

\section{Introduction}

In November 2006, after several previous failed attempts, voters in Kansas City approved a measure for the construction of a light rail transit (LRT) system that would be partly financed by a 3/8-cent sales tax for 25 years. According to the official ballot language, the plan proposes the construction of a new $\$ 1$ billion, 27-mile Heartland Light Rail system. The plan also proposes enlarging the light rail system's service area by employing a green fleet of 60 electric shuttles that would provide connecting transit service to nearby job and shopping centers. 


\section{Kansas City and Transportation}

During the 1990s, Kansas City embarked on a widespread strategic planning initiative. A key recommendation of the initiative involved the city's transportation system. Federal Highway Administration (FHWA) data indicated that the poor quality of Kansas City roads imposed annual vehicle operation costs of $\$ 651$ on Kansas City drivers' 1 the highest in the nation's major cities outside California. Data from the 2003 national Consumer Expenditure Survey indicated that among major metropolitan areas, Kansas City residents spent about 20 percent of their budget on transportation - the fifth highest in the nation. Kansas City offers no real alternatives to driving and, with continued growth, transportation is projected to become even more time-consuming and costly. As a result, a key recommendation of the planning initiative was for the development of a light rail transit system to "enhance the movement of people, to protect clean air, and to protect the natural environment ... and the promotion of more clustered development along transit corridors."

Kansas City is actually composed of two cities-Kansas City, Missouri and Kansas City, Kansas. Kansas City, Missouri is, by itself, the largest city in Missouri. The combined population of the greater Kansas City metropolitan area is close to 2 million. Once known primarily for agriculture and manufacturing, Kansas City today has a diversified economic base composed of telecommunications, banking, finance, and service-based industries. Kansas City is also a transportation hub and a major national distribution center. Transportation is, therefore, central to the continued development of Kansas City.

Notwithstanding the importance of transportation for Kansas City's economic development, recent investment in transportation infrastructure in Kansas City has been poor. In a study conducted by the Mid-America Regional Council (MARC), a regional public policy research organization located in Kansas City, Kansas City ranked at the bottom of a group of peer cities in terms of public transportation financing. The only public transit offered by the city is bus services. But even this service is underinvested; in fact, Kansas City would have to double its bus services to reach the average of its peer cities.

Due to the extensive highway projects implemented in Kansas City during the 1970s and 1980s, Kansas City possesses the most freeway lane miles per capita of all large urbanized areas in the United States and the fourth highest total roadway miles per person. ${ }^{3}$ Even though Kansas City ranks high in the number of roadway miles per person, its roads are in worse condition than national and peer city aver- 
ages. The Road Information Program's (TRIP's) 2004 Bumpy Roads Ahead report found that Kansas City's "poor" pavement conditions significantly exceeded national averages, and Kansas City had a smaller percentage of roads classified as "good." In addition, overall pavement conditions have notably deteriorated since 2000.

Transportation by automobile is, by far, the preferred mode of transportation in Kansas City, and recent studies indicate that reliance on automobiles is continuing to grow. More than 93 percent of all trips are by automobile, of which 83 percent are single-occupancy trips and 10 percent are carpool trips. About 4 percent work from home, 1 percent walk to work, and public transit accounts for the remaining 1 percent.

The extensive roadway system in Kansas City offsets the excessive reliance on automobiles; thus, congestion is not a major problem. However, there is significant congestion during peak periods, and nearly all studies are in agreement that congestion is growing. The 2001 Travel Time Study conducted by MARC found that congested travel as a percentage of peak vehicle miles traveled increased from 5 percent in 1982 to 32 percent in 2002. However, this still compares very favorably to other urban areas in which congested travel increased far more substantially, from 24 percent in 1982 to 65 percent in 2002. The low-density urban form of Kansas City means that travel distances in Kansas City are longer. The average vehicle miles of travel (VMT) per person in Kansas City was 28.65, whereas the average for metropolitan areas of similar size was 24.04 VMT per person each day. ${ }^{4}$ However, the relatively lower congestion in Kansas City results in greater travel speeds and shorter travel times. The MARC 2001 Travel Time Study found that even though average travel speeds steadily increased, "there are several routes where congestion is an increasing problem. This is evident in that there is a large percentage of routes and segments with delay ... and several of the most highly traveled routes in the region have significantly more delay than in previous studies." A similar study by the Missouri Department of Transportation found that of the 10 most heavilycongested sections of the urban Missouri interstate highways, 7 are located in Kansas City. ${ }^{5}$

\section{The Heartland Rail System}

Planning for the Kansas City LRT system began in the 1990s. The Technology Work Team considered six technology options-improved bus service, bus rapid transit 
with dedicated guideway (such as in Ottawa or Curitiba), electrified bus rapid transit (as in Lille, France or Mexico City), electrified street car, monorail and light rail-and settled on light rail as the preferred technology with electric bus transit as a second option.

The Heartland Rail system would serve some of Kansas City's densest residential neighborhoods in the mid- and south-town areas. The proposed system alignment runs through downtown Kansas City, serving an employment corridor with 250,000 jobs. The primary market that would be served by the proposed light rail system is work trips though strong connections to cultural and shopping centers would result in a strong secondary market. During peak weekday morning and evening periods, service is proposed to be provided every 12 minutes.

\section{Capital Costs, Operating Costs, and Funding for the Heartland Light Rail Project}

The Heartland Rail system, as proposed, would constitute one of the biggest infrastructural investments in Kansas City history. Detailed estimates of capital costs, cash inflows, and cash outflows for the project is provided in the Central Business Corridor ( $C B C)$ Transit Plan. The essential features of the project and the underlying project assumptions of the $C B C$ Transit plan are summarized in Table 1.

The $\mathrm{CBC}$ plan assumes that the project would be funded by three major sources. Federal funding of $\$ 593$ million was assumed to cover 60.50 percent of the capital costs of the project. A 3/8-cent sales tax for 25 years was assumed to generate $\$ 29$ million in the first year and a total of $\$ 878$ million over the 25 -year tax period. The project would also be funded by a $\$ 195$ million, 19-year, 7.70 percent bond issue, which would result in interest payments of $\$ 19.87$ million annually. The funding for the project would become effective on April 1, 2009.

\section{The Financial Economics of the Heartland Light Rail System- Project Analysis}

While detailed estimates of capital costs, cash inflows, and cash outflows over the 25-year life of the light rail system are provided in the Central Business Corridor (CBC) Transit Plan, there is no attempt to provide an economic or financial analysis of the project. The project inflow and outflow estimates provided by the CBC plan over the 25-year life of the project are shown in Table 2. 


\section{Table 1. Project Assumptions}

Project Life

- Capital Period

- Operating Period

Estimated (Inflation Adjusted) Capital Costs

Base Estimate of Annual Operating/Maintenance Costs

Annual Growth in Operating/Maintenance Cost

Annual Operating/Maintenance Cost in Year 9

$\left(\$ 15.20 \times[1+.04]^{8}=\$ 20.80\right)$

Total Operation and Maintenance Cost (Years 9 - 25)

Federal Capital Funding Percentage

Secondary Funds Base Assumption

(Annual Growth Rate 1.80\%)

Base Estimate from Sales Taxes

Estimated Annual Growth in Taxes

Tax Period

Bond Issue

Bond Repayment Period

Bond Interest Rate

Annual Bond Interest Payment

(\$195 million issue, Effective rate of $7.70 \%, 19$ years)

Base Estimate of Fare Revenue (Year 9 of project)

Annual Growth Rate in Fare Revenues
25 years

8 years (Year 1 - Year 8 )

17 years (Year 9 - Year 25)

$\$ 981$

$\$ 15.20$ million

$4 \%$

$\$ 20.80$ million

$\$ 493$

$60.50 \%$

$\$ 1.50$ million

$\$ 29$ million

$1.80 \%$

25 years

\$195 million

19 years

$7.50 \%$

\$19.87 million

$\$ 6.11$ million

$1.80 \%$ 


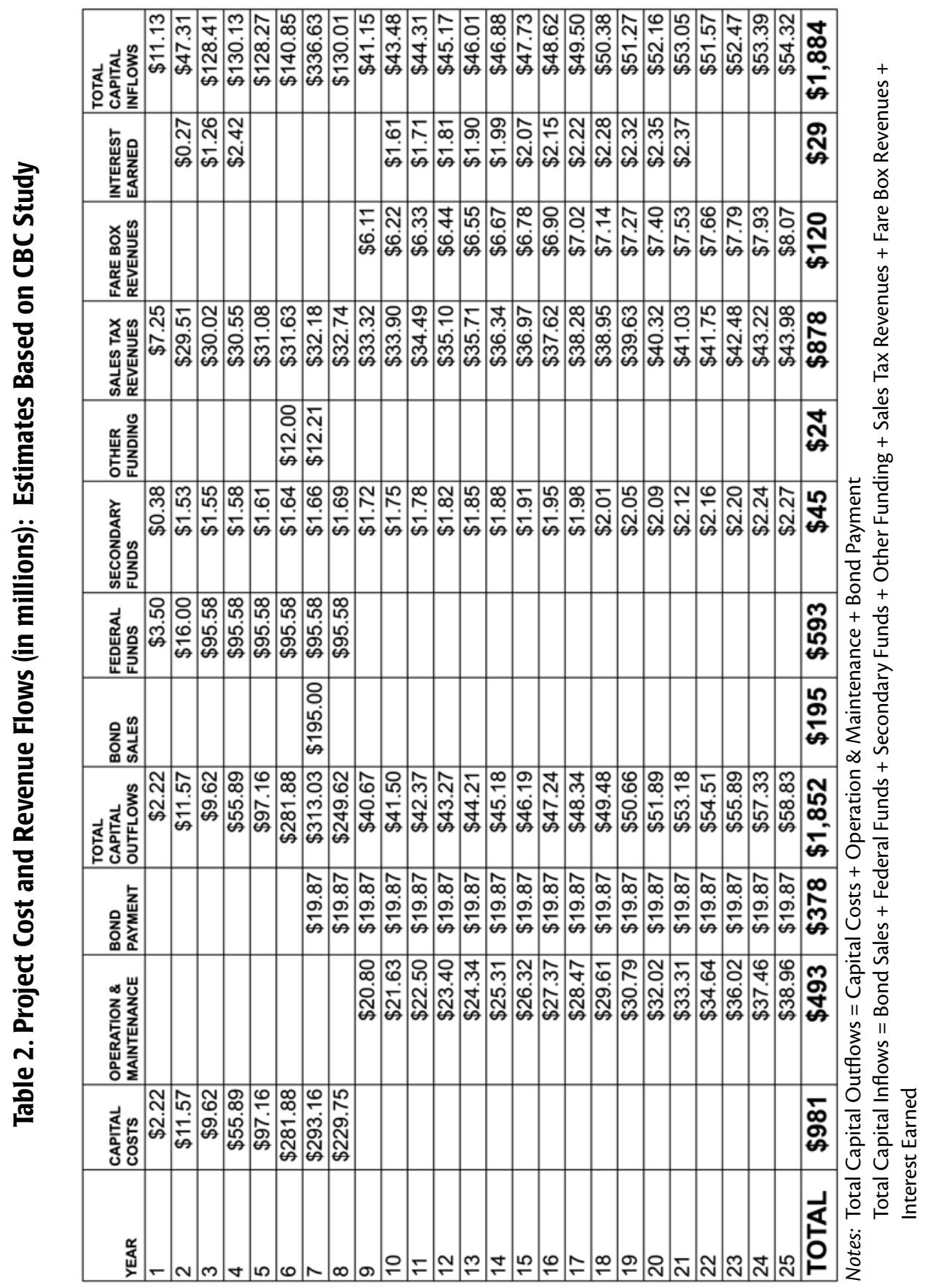


A good starting point for financial analysis is to compute the NPV of the Kansas City LRT project. For long-term capital projects, the Federal Transit Authority (FTA) recommends using a project discount rate of 7 percent. ${ }^{6}$ Using this as the applicable discount rate, the NPV of the project based on the CBC Transit Plan estimates turn out to be about $\$ 70$ million. However, this NPV value is based on preliminary estimates provided in the CBC Transit Plan and needs to be readjusted in the light of recent developments and other factors such as inflationary effects. The most significant revisions to the preliminary estimates are:

- The CBC Transit Plan estimates are based on operating cost assumptions of $\$ 20.80$ million. More realistic estimates suggest that operating costs would probably be in the range of $\$ 25-\$ 30$ million annually. The mid-point of this range is used here with the assumption (as in the CBC study) that operating costs escalate annually at 4 percent.

- The CBC Transit Plan revenue estimates are based on a $1 / 2$-cent sales tax assumption. The actual amount approved by Kansas City voters was $3 / 8$ cents. (Thus, actual sales tax revenues earmarked for the project are 25 percent lower.) The lower estimate suggests that a 3/8-cent sales tax would generate sales tax revenues of $\$ 23$ million annually. The $C B C$ estimates were revised to reflect the lower sales tax with the assumption (as in the CBC study) that sales tax revenues increase by 1.75 percent annually.

The revised estimates are shown in Table 3. The NPV of the project based on the net cash flows of the project turn out to be $-\$ 53.31$ million, while the Internal Rate of Return (IRR) is 10.58 percent $^{7}$-a clear signal that the project has some inherent problems.

What is clear from an analysis of the cash flow stream is that the project is heavilydependent on federal funding. Ironically, the only periods in which the project has any positive cash flow stream are the initial years-the periods when one would expect the project to run deficits because of high capital costs. This is due to the fairly high values assumed for federal funding. While capital costs reach a peak in years 6-8, a bond issue in Year 7 partially offsets some of these capital costs, resulting in a net inflow in Year 7.

The most instructive aspect of the financial analysis is the non-self sustaining nature of the project in the operating phase covering years 9-25. Net cash flows in the operating phase of the project are negative in every year of the project. In principle, the operating phase is somewhat less subject to uncertainty since the 


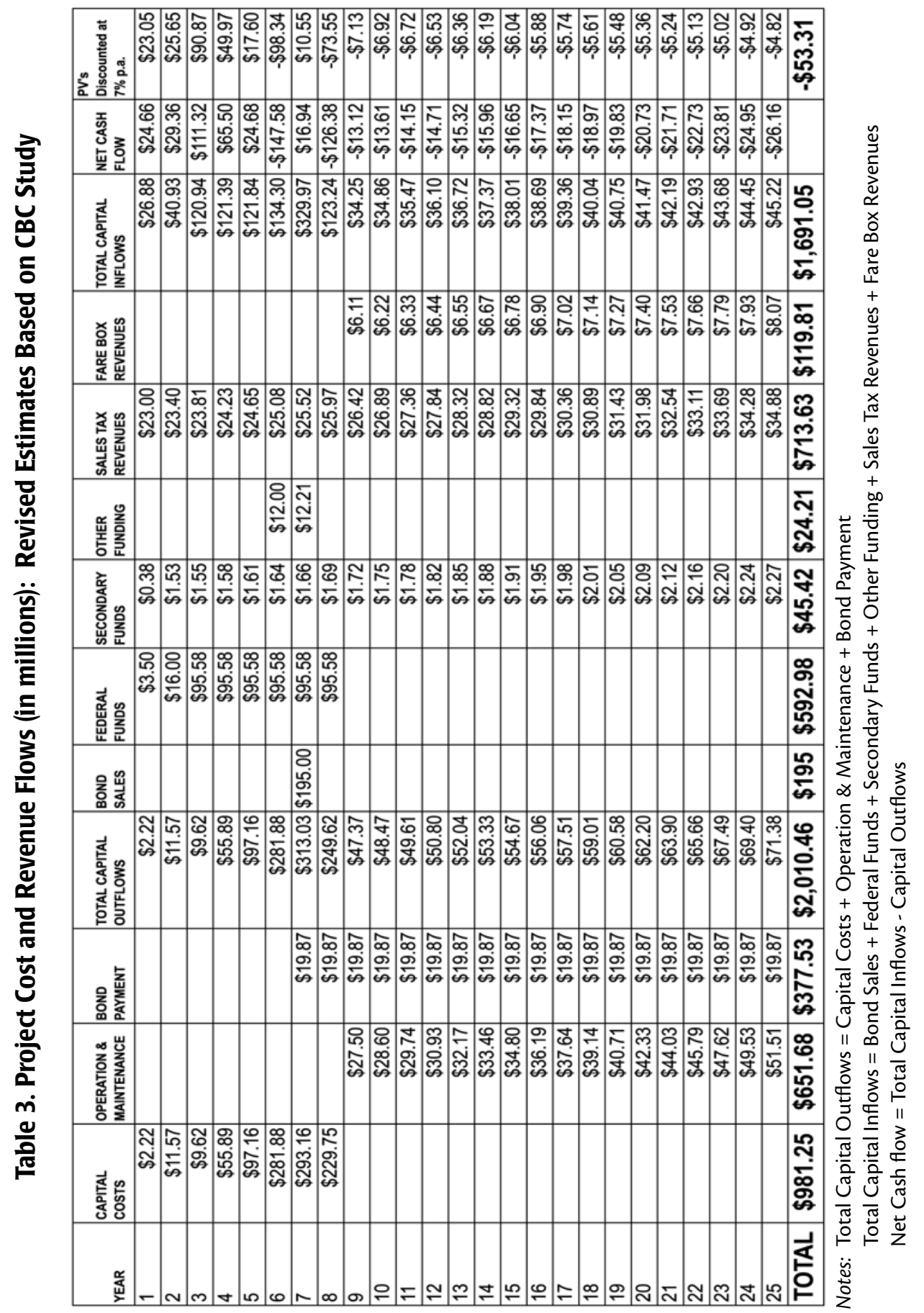


major uncertainty in infrastructural projects tends to center around the substantial initial investment costs. Four major factors determine the economic viability of the Heartland Light Rail project in the operating phase of the project: operating and maintenance costs, bond interest payments, sales tax revenues, and fare box revenues. The effect of each of these variables are analyzed below.

\section{Operating and Maintenance Costs}

The budgeted value for operating and maintenance cost in the first year of the K.C. Light Rail project is $\$ 20.80$ million. A more realistic estimate, taking into account factors such as cost escalation and inflation, is $\$ 25-\$ 30$ million. Using a mid-range estimate of operating costs, the NPV of the project, as pointed out earlier, turns out to be negative. Now, suppose one were to give the operating costs of the project more latitude. What is the lowest value that one could assume for base operating costs and still end up with a positive value for NPV? Holding everything else constant, the effect on NPV for different base year operating and maintenance cost assumptions is reported below. ${ }^{8}$

\section{Table 4. Project Sensitivity to Base Year Operating \& Maintenance Cost Assumptions}

\begin{tabular}{|c|c|}
\hline $\begin{array}{c}\text { Operating \& Maintenance } \\
\text { Cost (millions) }\end{array}$ & NPV (millions) \\
\hline $\mathbf{\$ 2 7 . 5 0}$ (Base Estimate) & $\mathbf{- \$ 5 3 . 3 1}$ \\
\hline$\$ 25$ & $-\$ 34.72$ \\
\hline$\$ 24$ & $-\$ 27.28$ \\
\hline$\$ 23$ & $-\$ 19.85$ \\
\hline$\$ 22$ & $-\$ 12.40$ \\
\hline$\$ 21$ & $-\$ 4.97$ \\
\hline$\$ 20.33$ & $\$ 0$ \\
\hline
\end{tabular}

Thus, operating and maintenance costs would have to be lower than $\$ 20.33$ million at inception of project operation for NPV to be positive. Given that the current estimate is $\$ 25$ million, it seems unlikely that operating and maintenance costs could go as low as $\$ 20.33$ million. In addition, if the annual percentage increase in operating costs were higher than 4 percent, the resulting NPV's would be even more unfavorable.

\section{Bond Interest Payments}

The base estimates are based on partial funding of the Heartland Light Rail Project through a $\$ 195$ million, 7.70 percent effective rate, 19-year bond issue in Year 7 of the project. This results in interest obligations of $\$ 19.87$ million over 19 years. How low would interest obligations have to be to result in a break-even NPV? 
The effective interest rate assumed for the Heartland Light Rail bond issue is 7.70 percent. Of course, future interest rates are unknown, but, based on Kansas City's current credit rating, an interest rate of 7.70 percent seems reasonable and perhaps even on the higher side. In 2007, Kansas City issued \$138 million of general obligation "GO series 2007A" bonds at a rate of 4.60 percent. All three credit rating agencies-Standard and Poor's, Moody's, and Fitch Ratings-affirmed their belief in the City's financial strength. In Table 5, a19-year bond issue of $\$ 195$ million is assumed, and the effect of different interest rates and debt servicing levels on project NPV is computed.

\section{Table 5. Project Sensitivity to Interest Cost Assumptions}

\begin{tabular}{|c|c|c|}
\hline Interest Rate & Annual Debt Servicing & NPV (millions) \\
\hline $4 \%$ & $\$ 14.85$ & $-\$ 18.74$ \\
\hline $5 \%$ & $\$ 16.14$ & $-\$ 27.62$ \\
\hline $6 \%$ & $\$ 17.48$ & $-\$ 36.85$ \\
\hline $7 \%$ & $\$ 18.87$ & $-\$ 46.42$ \\
\hline $7.50 \%$ & $\$ 19.58$ & $-\$ 51.31$ \\
\hline $\mathbf{7 . 7 0 \% ( B a s e ~ E s t i m a t e ) ~}$ & $\$ 19.87$ & $-\$ 53.31$ \\
\hline $8.50 \%$ & $\$ 20.30$ & $-\$ 56.27$ \\
\hline $9 \%$ & $\$ 21.04$ & $-\$ 61.37$ \\
\hline
\end{tabular}

Note: The above is based on a $\$ 195$ million, 19-year bond issue.

It is clear from the sensitivity analysis above that even if long-term interest rates were to decline to a historical low of 4 percent, the resulting savings in debt servicing costs is insufficient to result in a non-negative NPV. Since long-term interest rates have historically been around 7.50 percent, it is improbable for much savings to be realized from a decline in annual debt servicing costs alone.

Suppose we were to consider two other options-increasing the size of the bond issue or increasing the maturity of the issue. It is important to recognize that size, maturity, and annual payments are all simultaneously determined, so that changing any one variable affects the value of at least one of the other variables. Now suppose that the size of the issue was increased from $\$ 195$ million to some higher value while maturity of the issue is kept constant. What effect would this have on the NPV of the project? The results are reported in Table 6.

Clearly, increasing the size of the bond issue worsens the NPV of the project. This is due to the fact that while a larger bond issue increases the cash inflow in Year 7 , it also results in higher debt servicing burdens in the outer years of the project. In fact, a lower issue size may be the answer, but there may be constraints about running unacceptably high levels of deficits in the initial years of the project. 


\section{Table 6. Project Sensitivity to Bond Issue Size}

\begin{tabular}{|c|c|c|}
\hline Bond Issue & $\begin{array}{c}\text { Annual Debt } \\
\text { Servicing } \\
\text { Burden }\end{array}$ & NPV \\
\hline $\begin{array}{c}\text { \$195 (Base } \\
\text { Estimate) }\end{array}$ & $\$ 19.87$ & $\mathbf{- \$ 5 3 . 3 1}$ \\
\hline$\$ 200$ & $\$ 20.38$ & $-\$ 53.71$ \\
\hline$\$ 210$ & $\$ 21.40$ & $-\$ 54.51$ \\
\hline$\$ 220$ & $\$ 22.42$ & $-\$ 55.30$ \\
\hline$\$ 230$ & $\$ 23.43$ & $-\$ 56.03$ \\
\hline$\$ 240$ & $\$ 24.45$ & $-\$ 56.83$ \\
\hline$\$ 250$ & $\$ 25.47$ & $-\$ 57.63$ \\
\hline
\end{tabular}

Note: The above assumes an effective funding cost of 7.70 percent and a maturity of 19 years.

Would increasing the maturity of the bond issue and consequently reducing the annual debt servicing burden improve the NPV of the project? Suppose the size of the issue and interest rate remained at $\$ 195$ million and 7.70 percent, but the maturity of the issue was increased from 19 to 25 years. The annual debt servicing burden in this case would decrease from $\$ 19.87$ million to $\$ 17.80$ million over the life of the project, and NPV would improve from the base case NPV of $-\$ 53.31 \mathrm{mil}-$ lion to $-\$ 45$ million.

At an extreme, imagine that Kansas City could issue a perpetual bond. Suppose the issue size is $\$ 195$ million and the interest rate is 7.70 percent. In this case, the annuity payments would decline from the base case estimate of $\$ 19.87$ million per annum to perpetual annuity payments of $\$ 15.02$ million ( $\$ 195 \mathrm{~m} \times .0770)$. This is the lowest-possible annual debt servicing burden attainable by increasing bond maturity. However, this would still result in a negative NPV.

The bottom line is this: Declining interest rates and consequently a lower debt burden would improve NPV, but even at very low interest rates the project does not break even. Other solutions, such as increasing the size of the bond issue or increasing the maturity of the bond issue, are either not helpful or do not impact the NPV in any substantive manner.

\section{Sales Tax Revenues}

Initial estimates suggested a $1 / 2$-cent sales tax earmarked for the Heartland Light Rail project. Anti-tax sentiment is, however, very strong in Kansas City, and the final amount approved for the light rail project by Kansas City voters was a 3/8-cent tax for 25 years. The possibility for increasing the sales tax rate is remote; 
the ballot language is very specific, and no significant changes can be made without submitting any changes to a vote. Thus, increasing sales tax revenues to provide additional funding for the project seems unlikely.

\section{Fare Box Revenues}

The CBC Transit Plan assumes that fare box revenues in the first operational year of the project (Year 9 ) will be around $\$ 6.11$ million and increase roughly at the rate of 1.76 percent annually. Demand estimates of ridership are not provided in the $C B C$ Study, but one can extrapolate from the above value.

Assume a one-way fare price of $\$ 3$. At a single trip cost of $\$ 3$, the number of passenger boardings required to generate $\$ 6.11$ million is about 2.036 million per year or 8,146 weekday boardings ([ $\$ 6.11$ million] / [ $\$ 3 \times 250$ working days]). Assume for simplicity that 100 percent of the rides are generated by daily round trip commuters. This implies that the number of round trips assumed in the CBC study is 4,073 round-trips per working day. Thus, at a one-way trip price of $\$ 3$, the fare box revenue projections will be fulfilled if there are 4,073 daily round-trip commuters per working day. At a lower fare price of $\$ 2$ per one-way trip, it can similarly be determined that the required number of daily round trip commuters is 6,110.

Are the estimates for the number of riders above feasible? One way to answer this question is to look at the usage for current modes of transportation in Kansas City. Data from 2005 compiled by the U.S. Census Bureau on "Commuting to Work" indicates that, of the 914,000 daily commuters in the greater Kansas City metro area, an overwhelming number (800,0000 or $88 \%$ ) drove alone; 80,731 (9\%) carpooled, and 9,767 (1.07\%) used public transportation. Clearly, public transportation is not a preferred transportation mode in Kansas City. However, the assumed number of daily commuters in the CBC study $(4,073)$ - even given the disappointing number of current daily public transit users-seems low. The proposed Kansas City light rail system would serve a route corridor estimated to contain 250,000 workers. If 1.63 percent of these workers would choose to use light rail, the ridership estimates in the CBC study would be fulfilled.

Ridership estimates are invariably subject to varying degrees of error. Suppose the problem is looked at somewhat differently and a related question is asked. Holding everything else constant, what is the lowest estimate of fare box revenues that would result in a break even NPV? The model suggests that fare box revenues of $\$ 14.47$ million in the first year of the project (or more than twice the revenue assumed in the CBC Study) would result in a break-even NPV. Annual fare box 
revenues of $\$ 14.47$ million implies 14,470 round-trips per working day ([\$14.47 million] / [ $\$ 4$ round-trip cost $\times 250$ days]). In fact, if the one-way trip cost was increased to $\$ 2.50$ from $\$ 2$, the required number of round-trips per day would be even lower, at $11,576 .{ }^{\circ}$ While options relating to sales tax revenues, bond funding, maturity of the bond issue, etc., do not seem to hold much promise, estimates for ridership in Kansas City seem to hold more promise. The reason for this is counterintuitive: the very fact that regions like Kansas City are so poorly served by public transportation constitutes an advantage in the sense that a good public transit system has a great deal of potential and much room to grow.

How likely are the ridership estimates above? Does light rail hold promise for Kansas City? In this regard, the experience of St. Louis, Missouri may be instructive. In fact, if one wanted to use a reference city to draw a comparison with Kansas City, it would be difficult to come up with a better example than St. Louis. Besides being geographically proximate, both cities share strong cultural ties. St. Louis uses a light rail system called MetroLink, which consists of two lines that carry an average of 49,287 people each weekday. In 2006, a second line (Shrewsbury Line) opened for operation and within seven months reached ridership targets that were predicted to be reached eight years later. The St. Louis Dispatch (March 22, 2007) reported that "average weekday boardings vary month to month but were up 30,500 in January over the same month last year.... In four of the months since the line's inauguration in August, average weekday ridership surpassed 63,000-a number that transportation planners thought would not be reached until 2015." The St. Louis Dispatch argued that commuters, fed up with high gasoline prices and congested roadways, were finally beginning to consider public transportation as a serious alternative in the Midwest. If the experience of St. Louis is anything to go by, public transit's time may have finally arrived in Kansas City.

\section{Operating Costs, Capital Costs and Federal Funding for the Heartland Light Rail Project}

This section analyzes three aspects of the Heartland Light Rail project that are subject to a considerable degree of uncertainty-operating costs, capital costs, and federal funding - and then attempts to use the experience of other U.S. cities to construct realistic cost and funding estimates for the Heartland Light Rail Project. 


\section{Operating Costs}

Most criticism of light rail transit systems center around the high capital and operating costs of LRT systems as compared to bus systems. Table 7 compares operating costs for LRT and bus systems in 12 cities and then computes the operational cost savings from using a LRT system.

\section{Table 7. Comparison of Operating Expenses per Passenger Mile (PM) for LRT versus Bus Systems in Selected Cities (2003)}

\begin{tabular}{|l|c|c|c|c|c|c|c|}
\hline \multicolumn{1}{|c|}{ City } & $\begin{array}{c}\text { LRT } \\
\text { Annual } \\
\boldsymbol{P M} \\
\text { (millions) }\end{array}$ & $\begin{array}{c}\text { LRT } \\
\text { Annual } \\
\text { Operating } \\
\text { Expenses } \\
\text { (millions) }\end{array}$ & $\begin{array}{c}\text { LRT } \\
\text { Operating } \\
\text { Costs per } \\
\boldsymbol{P M}\end{array}$ & $\begin{array}{c}\text { Bus } \\
\text { Annual } \\
\boldsymbol{P M} \\
\text { (millions) }\end{array}$ & $\begin{array}{c}\text { Bus Annual } \\
\text { Operating } \\
\text { Expenses } \\
\text { (millions) }\end{array}$ & $\begin{array}{c}\text { Bus Annual } \\
\text { Operating } \\
\text { Expenses } \\
\text { per PM }\end{array}$ & $\begin{array}{c}\text { Annual } \\
\text { LRT } \\
\text { Operating } \\
\text { Savings } \\
\text { (millions) }\end{array}$ \\
\hline Baltimore & 48.5541 & $\$ 34.5015$ & $\$ 0.71$ & 333.5452 & $\$ 209.8312$ & $\$ 0.63$ & $-\$ 3.96$ \\
\hline Buffalo & 14.4435 & $\$ 17.0457$ & $\$ 1.18$ & 73.3945 & $\$ 78.7543$ & $\$ 1.07$ & $-\$ 1.55$ \\
\hline Dallas & 120.6741 & $\$ 57.5433$ & $\$ 0.48$ & 248.0237 & $\$ 202.3335$ & $\$ 0.82$ & $\$ 40.90$ \\
\hline Denver & 45.4951 & $\$ 20.0682$ & $\$ 0.44$ & 325.0310 & $\$ 217.4397$ & $\$ 0.67$ & $\$ 10.37$ \\
\hline $\begin{array}{l}\text { Hudson- } \\
\text { Bergen }\end{array}$ & 25.8854 & $\$ 48.4832$ & $\$ 1.87$ & 921.9889 & $\$ 550.5370$ & $\$ 0.60$ & $-\$ 33.03$ \\
\hline Los Angeles & 225.7119 & $\$ 86.2001$ & $\$ 0.38$ & 1440.5470 & $\$ 744.3132$ & $\$ 0.52$ & $\$ 30.42$ \\
\hline Portland & 169.5716 & $\$ 55.2959$ & $\$ 0.33$ & 237.3450 & $\$ 171.4024$ & $\$ 0.72$ & $\$ 67.16$ \\
\hline Sacramento & 47.3649 & $\$ 30.3754$ & $\$ 0.64$ & 75.3255 & $\$ 68.3854$ & $\$ 0.91$ & $\$ 12.63$ \\
\hline Salt Lake City & 55.2055 & $\$ 19.9264$ & $\$ 0.36$ & 91.1734 & $\$ 83.8204$ & $\$ 0.92$ & $\$ 30.83$ \\
\hline San Diego & 159.3564 & $\$ 38.9859$ & $\$ 0.24$ & 121.9353 & $\$ 66.8389$ & $\$ 0.55$ & $\$ 48.37$ \\
\hline $\begin{array}{l}\text { Santa Clara/ } \\
\text { San Jose }\end{array}$ & 26.8153 & $\$ 50.9434$ & $\$ 1.90$ & 153.5307 & $\$ 213.6926$ & $\$ 1.39$ & $-\$ 13.62$ \\
\hline St. Louis & 124.9726 & $\$ 36.7070$ & $\$ 0.29$ & 122.1657 & $\$ 107.0455$ & $\$ 0.88$ & $\$ 72.80$ \\
\hline
\end{tabular}

Source: These values are derived from Table 12 (Transit Operating Expenses by Mode, Type of Service and Function) and Table 19 (Transit Operating Statistics: Service Supplied and Consumed) of the National Transit Database (NTB) 2003 figures. Annual LRT Operating Savings is computed by considering the cost advantage of LRT over bus systems and then multiplying the result by the number of annual LRT passenger miles. Note that negative figures imply that LRT is more expensive than the bus system in that city. Values do not add up exactly because of rounding. ${ }^{10}$

Clearly, LRT systems in most cities result in lower operating costs than bus systems. ${ }^{11}$ The results reported above can be reinforced by looking at the most recent data available from the National Transit Database on annual operating costs for LRT and bus systems for the U.S. as a whole. 


\section{Table 8. Comparison of Operating Expenses for Light Rail and Bus Systems in the U.S.}

\begin{tabular}{|l|c|c|}
\hline & Light Rail & Bus System \\
\hline Annual Operating Expense (millions) & $\$ 1,070.1$ & $\$ 15,796.5$ \\
\hline Annual Passenger Miles (millions) & $1,865.7$ & $20,390.2$ \\
\hline Average Cost per Passenger Mile & $\$ .57$ & $\$ .77$ \\
\hline
\end{tabular}

Source: See 2006 National Transit Profile, National Transit Database.

An approximation of the operational cost benefit of LRT systems over bus systems for the U.S. as a whole can be calculated thus. Since operating cost per LRT passenger mile is $\$ .20$ cheaper than bus systems, and LRT accounted for 1,865.7 million passenger miles, the annual cost savings from LRT systems for the U.S. as a whole in 2006 was about $\$ 373$ million.

The bottom line is that operating costs are not a reasonable basis on which to criticize LRT systems. The empirical evidence is reasonably clear that operating expenses for LRT systems are lower than bus systems. Based on this experience, it can reasonably be concluded that, over the long run, operating expenses of the Heartland Light Rail would probably be lower than bus operating costs.

\section{Capital Costs}

Even though operating costs of LRT systems are, on average, lower than bus systems, the capital costs of light rail systems are another matter. Data on construction costs of light rail systems are not easily available. A recent paper by Baum-Snow and Kahn (2005) uses a variety of sources to provide an estimate of construction costs for major rail transit projects. ${ }^{12}$ The data reveal wide variations in construction costs, depending on the type of construction (see Table 9). The least-expensive lines are typically those that are built on the surface either as upgrades of existing railroad lines or on city streets. At the other extreme are bored tunnel lines, which can cost more than $\$ 300$ million per mile. For instance, Seattle's new LRT system is expected to cost $\$ 179$ million per mile, while at the other extreme the LRT systems in Baltimore, Sacramento, and Salt Lake City cost less than $\$ 20$ million per mile. Since most of these systems were built at different points in time, it is difficult to directly compare capital costs. Table 9 reports capital costs for major LRT projects in 2003 dollars ${ }^{13}$ to facilitate comparison with the LRT and bus operating cost data reported in Table 7. These capital costs are then amortized over 30 years at 7 percent per annum and reported in the third column of the table. ${ }^{14}$ Utilizing data from Table 7 , the last column reports the annual 


\section{Table 9. Estimated Light Rail Capital Costs}

\begin{tabular}{|l|c|c|c|}
\hline \multicolumn{1}{|c|}{ City } & $\begin{array}{c}\text { LRT Capital Costs } \\
\text { (millions of 2003 } \\
\text { dollars) }\end{array}$ & $\begin{array}{c}\text { Annualized } \\
\text { Capital Costs } \\
\text { (30 years, } \\
\mathbf{7 \% )}\end{array}$ & $\begin{array}{c}\text { Annual LRT } \\
\text { Operational } \\
\text { Savings (millions } \\
\text { of 2003 dollars) }\end{array}$ \\
\hline Baltimore & $\$ 757$ & $\$ 61$ & $-\$ 3.96$ \\
\hline Buffalo & $\$ 1,007$ & $\$ 81$ & $-\$ 1.55$ \\
\hline Dallas & $\$ 1,540$ & $\$ 124$ & $\$ 40.90$ \\
\hline Denver & $\$ 413$ & $\$ 33$ & $\$ 10.37$ \\
\hline Hudson-Bergen & $\$ 1,128$ & $\$ 91$ & $-\$ 33.03$ \\
\hline Los Angeles & $\$ 2,028$ & $\$ 163$ & $\$ 30.42$ \\
\hline Portland & $\$ 1,538$ & $\$ 124$ & $\$ 67.16$ \\
\hline Sacramento & $\$ 302$ & $\$ 24$ & $\$ 12.63$ \\
\hline Salt Lake City & $\$ 451$ & $\$ 36$ & $\$ 30.83$ \\
\hline San Diego & $\$ 997$ & $\$ 80$ & $\$ 48.37$ \\
\hline San Jose & $\$ 1,024$ & $\$ 83$ & $-\$ 13.62$ \\
\hline St. Louis, MO & $\$ 918$ & $\$ 74$ & $\$ 72.80$ \\
\hline
\end{tabular}

Note: The last column is derived from Table 7.

operational cost savings from using an LRT system. In comparing columns 3 and 4 , it is evident that, in every case, the amortized annual capital cost of LRT systems are invariably higher than the operational cost savings generated by LRT systems.

Since operational savings of LRT systems do not cover their capital costs, a common argument is to expand bus service as a more feasible alternative to investing in capital intensive light rail projects. A recent paper by Thompson and Matoff (2003) analyzes bus systems in selected cities and comes to the conclusion that "regions that choose to improve their public transit systems based on express buses do not escape making heavy capital expenditures"(p. 311). Thompson and Matoff also point out that arguments based on "saving" money on capital investment projects and routing those savings to expanding bus services seem fallacious. They point out that:

The region that made the smallest capital investment in its transit systemColumbus-severely reduced the amount of service that it provided per capita. If the position of the critics were correct, Columbus, by not "wasting" funds on capital investment, should have had large resources left over to greatly expand its bus service; obviously, that has not happened.... It is clear that transit agencies that have pursued development of multidestinational networks that include rail 
for trunk lines have been able to generate significant ridership without sacrificing effectiveness, efficiency or equity. (p. 311).

As pointed out earlier, the wide variations in capital costs of LRT systems arise primarily from the type of construction as well as factors like right of way acquisition costs. If one considers only projects since 2000 (and ignores an outlier such as Seattle), the approximate average construction costs per mile of an LRT system is about $\$ 35$ million per mile. A base estimate for the Heartland Light Rail project, then, is $\$ 945$ million ( $\$ 35$ million per mile $\times 27$ miles). This value is, in fact, the same as that assumed in the Kansas City light rail ballot initiative. If one makes allowances for cost escalations and inflation, a reasonable capital cost estimate for the Heartland Light Rail project is about $\$ 1$ billion. This value is used in the subsequent sensitivity analysis.

\section{Federal Funding}

Even though the dollar value of federal capital funds assistance to transit agencies has been increasing over the last decade, the percentage contributed by federal agencies has been generally falling. The percentage of federal funding assumed in the Central Business Corridor Transit Study is 60 percent. This is an unrealistically high percentage that is out of line with the realities of current federal capital funding. The most recent data from the National Transit Database suggests that the current level of federal assistance is about 39 percent. This is used as a base value for federal assistance in the subsequent analysis.

In light of the above, previous values assumed in the Central Business Corridor plan are readjusted to reflect the current realities of capital costs and federal funding. In addition, the operating phase of the project is adjusted to be 25 years rather than the 17 years assumed in the Central Business Corridor study. The revised capital/ operating phase, cost, and revenue assumptions are reported in Table 10.

The NPV based on these results is not encouraging. The Heartland Light Rail project consistently runs a loss in almost every year, with the result that the project NPV is about $-\$ 343$ million. (See the last column of Table 11 for the discounted project cash flow estimates). Given that capital and operating costs are not subject to a decrease, the only way that the project would be viable is if fare box revenues were to increase dramatically. What would fare revenues need to be for the project to break even? The financial model indicates that fare box revenues would have to be $\$ 52.27$ million in the first year of the project with ridership increasing at 2 percent p.a. over the 25 -year operating phase of the project. At a single-trip fare 


\section{Table 10. Revised Project Cost/Revenue Assumptions}

\begin{tabular}{|c|c|}
\hline CAPITAL PHASE: & 8 years \\
\hline OPERATING PHASE: & 25 years \\
\hline \multicolumn{2}{|l|}{ COST ASSUMPTIONS } \\
\hline Capital Costs: & $\$ 125$ million for 8 years, or $\$ 1$ billion \\
\hline Operating and Maintenance Costs: & $\$ 27.50$ million in Year 9 and increasing at $4 \%$ p.a. \\
\hline Bond Interest Costs: & $\begin{array}{l}\$ 16.83 \text { million per year for } 30 \text { years (Year } 4 \text {-Year } \\
3 \text { at } 7.70 \% \text { ) }\end{array}$ \\
\hline Project Discount Rate: & $7 \%$ p.a. \\
\hline \multicolumn{2}{|l|}{ REVENUE ASSUMPTIONS } \\
\hline Federal Funding: & $\begin{array}{l}\$ 48.75 \text { million for } 8 \text { years, or } \$ 390 \text { million, representing } \\
39 \% \text { of capital costs of project }\end{array}$ \\
\hline Bond Issue: & $\$ 195$ million, 30-year bond issued in Year 3 of project \\
\hline Sales Tax Revenues: & $\begin{array}{l}\$ 23 \text { million in Year } 1 \text {, growing at } 1.75 \% \text { p.a. for } 25 \\
\text { years, based on } 3 / 8 \text { cent sales tax }\end{array}$ \\
\hline Fare Box Revenues: & $\begin{array}{l}\$ 10 \text { million in Year } 9 \text {, based on } 10,000 \text { round-trip } \\
\text { commuters per working day and a round-trip fare of } \$ 4 \text {. } \\
\text { Annual growth in fare revenues is assumed to be } 2 \% \text {. }\end{array}$ \\
\hline
\end{tabular}

of $\$ 2.50$, with a fare revenue of $\$ 52.27$ million, implies 20.908 million annual passenger boardings, or 41,816 weekday round-trip boardings. This level of ridership is not unattainable. The most recent data available from the St. Louis Metrolink system indicate that, over the annual period from July 2006 to June 2007, the Metrolink system accommodated 16.885 million or 33,772 round-trip weekday boardings ${ }^{15}$-an increase of 43 percent over the previous year. Moreover, the Kansas City transit corridor contains 250,000 jobs and an estimated population of about 300,000 within $1 / 2$ to $3 / 4$ miles of the transit corridor. ${ }^{16}$ If these two factors are anything to go by, a weekday ridership that would eventually result in a project breakeven for the Kansas City LRT system is not out of the question. 


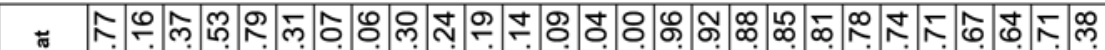

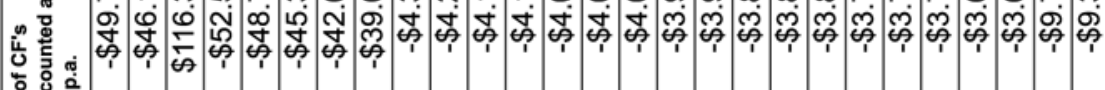

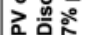

I

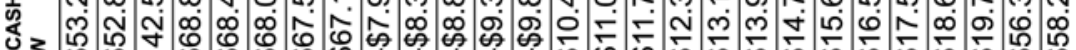

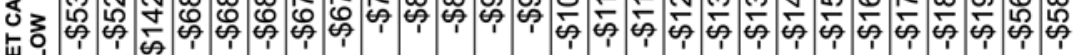
楸崖

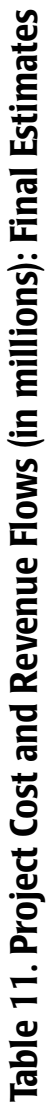

l. E

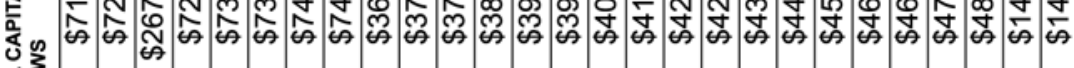
它号

온

있

崖

近崖

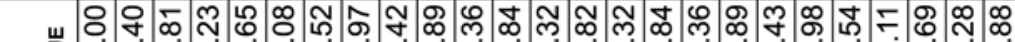

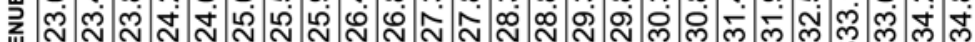

峁

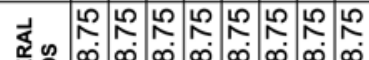

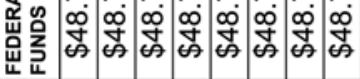

응

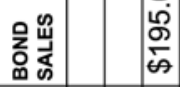

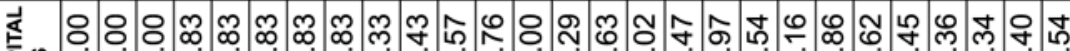

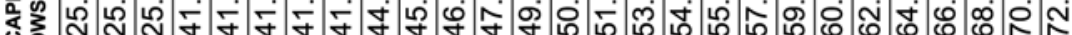

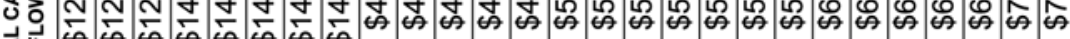

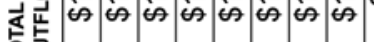

응

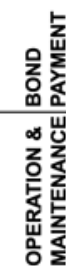

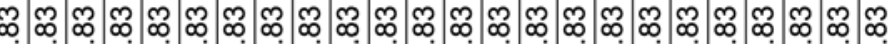

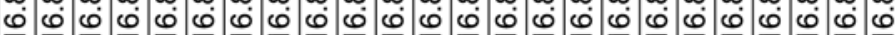

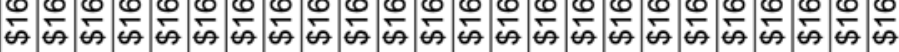

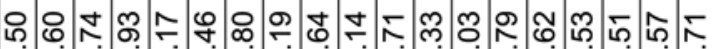

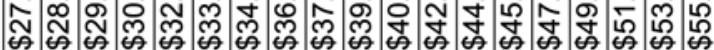

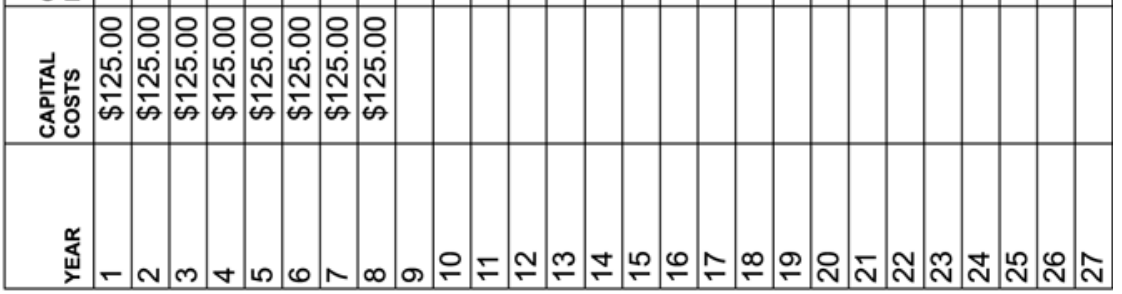




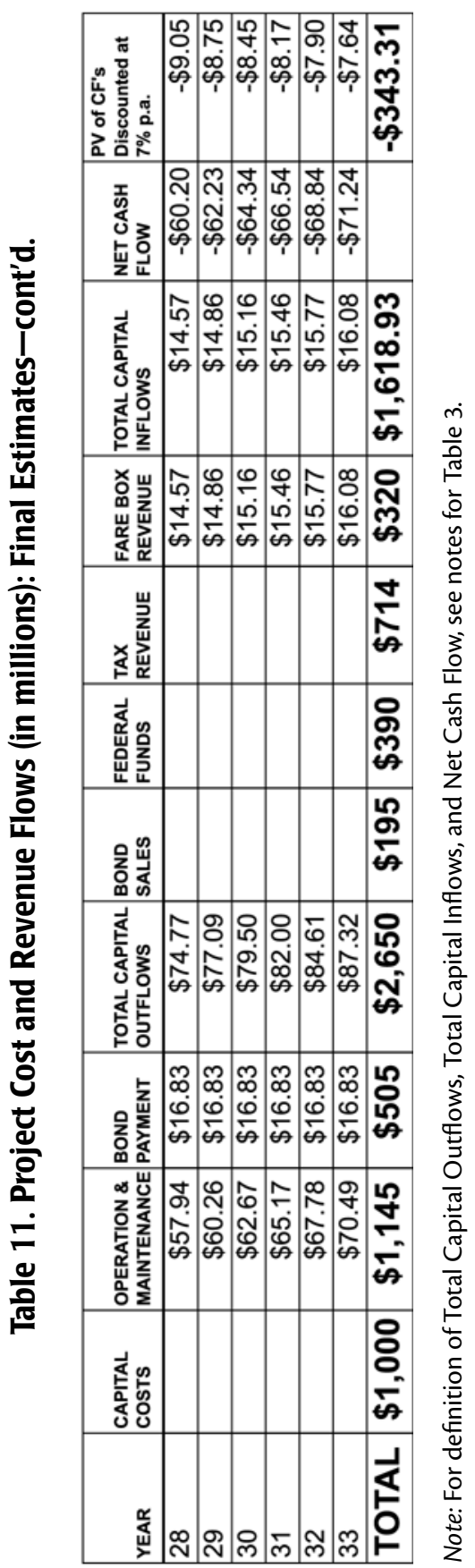




\section{Social Cost-Benefit Analysis of the Heartland Light Rail Project}

An important aspect to recognize about financial analysis is that, even though financial analysis of projects is invariably useful, the finances involved in a project essentially represent transfer payments between different economic entitiese.g., from federal taxpayers to local economies or from one group of tax payers to another. A more comprehensive analysis should take into account the economic/ social costs and benefits generated by infrastructural projects. The previous section implied that daily round trip ridership of the Heartland Light Rail project would have to be about 42,000 for the project to break even. Suppose the actual level of ridership falls far short of this level? Could the project still be justified based on other social benefit/social cost arguments?

There is a logical reason for the inability of most mass transit systems to be profitable. After a century of massive government investment in roads and highways, the cost of motor vehicle transportation is subsidized to such an extent that public transit systems find it impossible to raise fares by enough to be operationally selfsufficient. Vuchic (1999) ${ }^{17}$ referring to a study by the U.S. Office of Technology Assessment (OTA) estimates that car drivers pay only about 60 percent of the total costs of their travel while the other 40 percent (highway construction costs, maintenance costs, etc.) is subsidized by different levels of government. Other implicit costs, such as free parking, are subsidized by employers, store owners, schools, etc., while various social and environmental costs are absorbed by society. It is, thus, hardly surprising that public transit systems are unable to compete against motor vehicle transportation. Henry and Dobbs $(2005, \text { p.3 })^{18}$ make a similar argument:

The competing roadway-based transportation systems ... have been structured to minimize motorists' out-of-pocket costs. The high costs of private motor vehicle travel are covered by a largely unobtrusive umbrella of public and private subsidization as well as the transfer of "external costs" (like accidents and air pollution) to the general public.... Against this heavily subsidized, government promoted competition, public transport operators find it impossible to charge fares high enough to secure "profitable" operation."

An estimate of the costs of auto transportation should, therefore, take into account the externalities imposed by auto traffic such as congestion, accidents, pollution, time delays, etc. Several studies provide estimates of the total cost of motor vehicle use. Among the most comprehensive are those by Delucchi (1996), Small (1997), Small (1999), Delucchi (1997), ${ }^{19}$ and Delucchi (2000). While the 
1996 and 1997 studies by Delucchi provide estimates of the total cost of all motor vehicle usage, Delucchi (2000) breaks down the external costs of motor vehicle usage into costs for different transportation modes. Table 12 includes Delucchi's estimates of the external costs of the two primary competing modes considered in this section-auto transportation and light rail transportation. ${ }^{20}$

\section{Table 12. External Costs of Passenger Transportation Modes (cents per vehicle mile)}

\begin{tabular}{|l|c|c|}
\hline \multicolumn{1}{|c|}{ Cost Item } & Gasoline Auto & Light Rail \\
\hline Air Pollution & .80 to 13 & 5 \\
\hline Oil Use, Water Pollution & .30 to 1.50 & 1 \\
\hline Noise & .01 to 2.0 & 1 \\
\hline Congestion & 4.0 & - \\
\hline Accidents & 2.50 & 2 \\
\hline Highway Service Costs & .10 & 0 \\
\hline Unpriced Parking & 0 to 8 & 0 \\
\hline Inefficient Highway User Taxes and Fees & -2.70 & 0 \\
\hline Total Cents per Vehicle Mile & 5 to 28.4 & 9 \\
\hline Passengers per Vehicle Mile & 1.0 & $25.70(\mathrm{avg})$ \\
\hline Total Center per Passenger Mile & $\mathbf{5}$ to 28.40 & $\mathbf{3 5}$ \\
\hline
\end{tabular}

The possible range of external costs per passenger mile for autos is 5 to 28 cents, or a mid-point cost estimate of 11.70 cents. If one subtracts the external cost of .35 cents for light rail from this figure, the result (approximately 11 cents) constitutes an estimate of the external cost benefit provided by light rail over auto transportation. To this figure of 11 cents per passenger mile we need to add other positive externalities provided by LRT that were not explicitly valued in the Delucchi study. These include land use impact, preservation of wetlands, land erosion control, emission reduction benefits, conservation of non-renewable resources, rising property values around rail corridors, revitalization of transit corridors, enhanced mobility for the transit dependent, etc. In the current situation of rising gasoline prices, these positive externalities are likely to be considerable.

Quantifying the social benefits that arise from light rail is not easy. While operating and capital costs of light rail are explicit and thus easily quantified, many of the social benefits conferred by light rail are implicit and therefore easily ignored in policy debates. The problem of overlapping benefits and double counting involved in quantifying external benefits adds to the uncertainty surrounding such estimates. However, such social benefits could, in fact, be considerable. The following examples from the literature provide some notion of the dollar values attributed to these externalities. ${ }^{21}$ McPhearson et al. (1997) estimate that increas- 
ing tree cover by 10 percent saves annual heating and cooling costs by $\$ 50$ to $\$ 90$ per dwelling. They also estimate the NPV of a single tree to be $\$ 402$. Riddel (2001) estimates that as a result of 15,000 acres of open space, housing prices in Boulder, Colorado increased an average of $\$ 10,000$ for median-priced homes. Roe, Irwin and Morrow-Jones (2004) found that a 10 percent increase in the amount of farmland led to a rise in housing prices of $\$ 394$ for lower priced homes and about $\$ 1,100$ for higher priced homes. Kiker and Hodges (2002) estimated the economic benefits of natural lands in Northeast Florida at $\$ 2.6$ billion per year. A subsequent study by Kroeger (2005) extended the Kiker and Hodges' work to other types of benefits and arrived at an even higher value of $\$ 3.2$ billion per year. ${ }^{22}$ Table 13 summarizes the cost estimates provided by various studies on land use impact effects: ${ }^{23}$

\section{Table 13. Land Use Impact of Auto Travel}

\begin{tabular}{|l|c|}
\hline \multicolumn{1}{|c|}{ Cost Category } & $\begin{array}{c}\text { Estimate } \\
\text { (cents per vehicle mile) }\end{array}$ \\
\hline Environmental & 2.50 \\
\hline Aesthetic \& Cultural & 0.50 \\
\hline Social Costs & 2.50 \\
\hline Public Service (Municipality) Costs & 2.30 \\
\hline Transportation (Reduced Access) & 6.20 \\
\hline Total Sprawl Costs & 14.00 \\
\hline Passengers per Vehicle Mile & 1.0 \\
\hline Total Cents per Passenger Mile & $\mathbf{1 4 . 0 0}$ \\
\hline
\end{tabular}

The land use impact estimates in Table 13 are subject to a substantial degree of uncertainty. Some of the effects reported above may be double counted; other effects are ignored since they simply cannot be easily quantified. The most significant of the non-quantified effects is the effect of light rail transit on property values. Suppose for the time being we ignore this effect. The fundamental political issue then centers on whether the "subsidy" to rail transit (the negative NPV of $\$ 343$ million that was computed in the earlier section) could be offset by the implicit positive externalities conferred by the LRT system. How large would these externality benefits need to be? A negative NPV of $\$ 343$ million over 33 years discounted at 7 percent p.a. implies that the LRT system would have to confer annual benefits of $\$ 26.89$ million every year for 33 years for the project to break even. Are savings of such magnitude feasible?

The external cost estimates above imply that a conservative estimate of the net external cost savings from light rail over auto transport is about 11 cents per passenger mile. The land use impact savings from LRT adds another 14 cents, for a 
total of 25 cents. Since there is almost certainly some element of double counting between Delucchi's estimates and the land use impact effects reported in Table 13 , assume that the land use impact effect is not 14 cents but only half as much, or 7 cents. This results in a net external cost savings of 18 cents per passenger mile. Given that the average driver's round-trip work commute is about 30 miles per day in Kansas City, ${ }^{24}$ this implies that annual external cost savings would be $\$ 26.89$ million if the number of cars would decrease by 19,919 per workday $(\$ .18 /$ mile $x$ 30 miles/day x 250 days/year x 19,919 cars). ${ }^{25}$ In other words, if 19,919 cars were taken off the roads because of a travel mode shift from auto travel to light rail transit, the Heartland Light Rail project would be justifiable based on the savings in external costs alone.

The external cost savings of 18 cents per mile is one possible estimate of external costs. A larger estimate of external costs is provided in a comprehensive study conducted by the Victoria Transport Policy Institute (VTPI) on the externalities imposed by motor vehicle travel. The VTPI study considers 20 different cost categories separated into internal and external costs, including such external costs as parking, congestion, land value, transport diversity, pollution, noise, barrier effects, waste, etc.,and estimates such external $\operatorname{costs}^{26}$ at 59 cents per vehicle mile, more than three times the 18 cents in external cost savings considered earlier. This implies that the required decrease in the number of cars is even lower at 6,077 cars per work day to generate the equal annuity amount of $\$ 26.89$ million $(\$ .59 / \mathrm{mile} x$ 30 miles/day $\times 250$ days/year $\times 6,077$ cars). ${ }^{27}$

It should be noted that the external cost estimates used above do not take into consideration the effect that light rail would have on property values. The Central Business Corridor Transit Plan estimates that the Heartland light rail project would stimulate new investment of more than U\$ 1 billion, increase employment by about 13,000 and provide new annual taxes of about U\$17 million. ${ }^{28}$ If these property impact estimates are even marginally correct, it is then quite probable that the substantial overhead costs involved in light rail would essentially pay for itself through its externality effects.

\section{Conclusion}

The Heartland Light Rail project represents Kansas City's biggest infrastructural investment in decades. The ballot initiative for the light rail project was voted down three times until it was finally approved in November 2006. The very fact 
that the light rail project idea was so resilient in the face of strenuous opposition provides some evidence that LRT may be an idea whose time has finally arrived in Kansas City.

A strict financial analysis of the project is not encouraging. Using best estimates of construction costs, operating expenses and federal funding, the NPV of the project is estimated to be negative $\$ 343$ million. However, if one were to include the annual savings in external costs from lower auto travel, the Kansas City light rail project becomes an increasingly attractive option.

Since light rail projects involve substantial public funding a debate on their costs and benefits appropriately belongs in the domain of public policy. A major problem, however, in rationally evaluating the merits of such projects is that the public dialogue is often complicated by studies that make their case by either considering only costs that are explicit or ignoring non-monetized, implicit social benefits. The truth seems to be that if evaluated on a strict financial basis alone, light rail systems are unlikely to be completely self-sufficient. However, if light rail losses are not of such a magnitude that the project is completely unfeasible, it is very probable that social benefits could still render such projects worthwhile.

\section{Acknowledgements}

The author would like to express his appreciation to Prof. Jose Gomez-Ibanez of Harvard University's Kennedy School of Government for very helpful comments on an earlier draft of the paper. He would also like to thank Todd Litman of the Victoria Transport Policy Institute for helpful suggestions. All errors are the author's sole responsibility.

\section{Endnotes}

1 The Road Information Program (TRIP), "Rough Ride in the City: Metro Areas with the Roughest Rides and Strategies to Make our Roads Smoother," October 2006.

2 “Central Business Corridor Transit Plan," Final Report, April 27, 2001.

3 These data are from the 2003 Highway Statistics published by the Federal Highway Administration (FHWA).

4 See the Texas Transportation Institute's 2004 Urban Mobility Study. 
5 See Chart 3 (page 16) of The Road Information Program (TRIP), "Rough Ride in the City: Metro Areas with the Roughest Rides and Strategies to Make our Roads Smoother," October 2006.

6 Typically, a project's cost of capital should be computed as a weighted average cost of capital (WACC) where the weights are the proportions of debt and equity and the costs pertain to the cost of debt and cost of equity. The cost of equity is typically determined using the Capital Asset Pricing Model (CAPM). This method of estimating WACC is inapplicable for publicly funded projects since no equity is issued. An approximate cost of capital for the Kansas City LRT project can be determined thus. The cost of capital of a project is linked to the risk of the underlying assets supporting the project. In 2007, Kansas City issued General Obligation (GO) bonds at a yield of $4.60 \%$. Assuming that the LRT project is more risky than Kansas City's asset base, we can add a "premium" over the yield of Kansas City GO bonds. Adding a premium of 200 basis points or $2 \%$ results in the assumed project cost of capital of 7\%. For a detailed discussion of project valuation see Chapter 19 of Principles of Corporate Finance, "Financing and Valuation," Brealey, Myers and Allen (2006).

7 Note that the project is non-normal-that is, negative cash flows occur during the life of the project. In such situations, the IRR criterion can be misleading. In the subsequent analysis, the IRR values are not reported for this reason.

8 I continue to assume that operating costs will increase by $4 \%$ p.a. from the base year estimate of operating and maintenance costs.

9 Given that the American Public Transportation Association has estimated that the total cost of riding public transportation (including transfers, parking, etc.) at a base fare of $\$ 2.50$ is $\$ 2454$ /year versus estimated driving costs for midsize cars of $\$ 8,580 /$ year, public transportation seems a bargain. However, whether the public perceives it this way, especially in auto dependent areas like Kansas City, remains to be seen.

${ }^{10}$ Some of these values are also reported in Toole (2005), "Does Light Rail Pay for Itself?" (see www.ti.org/vaupdate57.html). I follow a similar logic to that in the article in determining operational cost savings for light rail. The sample set of cities reported in the table is limited to those cities for which construction costs for light rail are available. This is to facilitate a comparison of operational cost with capital costs. See a subsequent section of this paper. 
${ }^{11}$ An important part of the reason is that since light rail systems serve the densest transit corridors, operational costs for light rail generally tend to be lesser than low passenger density serving bus systems.

${ }^{12}$ See Table 1 of Baum-Snow and Kahn (2005). Data for LRT capital costs in some major cities is unfortunately not available. For instance, data on capital costs for both D.C. and Chicago's rail transit system are unavailable.

${ }^{13}$ Construction cost data from the Baum-Snow and Kahn (2005) paper is converted into 2003 dollars and reported in Toole (2005), "Does Light Rail Pay for Itself?" (see www.ti.org/vaupdate57.html).

${ }^{14}$ The average life span of rail hardware is 30 years. The amortization rate of $7 \%$ is prescribed by the Federal Transit Administration (FTA) for amortizing capital costs. See Toole (2005).

15 "Metro System Ridership" numbers reported on www.metrostlouis.org

${ }^{16}$ This estimate is contained in the Kansas City Long Range Transportation Plan, Figure 5-7, pp. 5-13. See also Exhibits 1 and 2 that depict the spatial and demographic characteristics of the primary transit corridor.

${ }^{17}$ Vuchic, Transportation for Livable Cities, Center for Urban Policy Research, Rutgers University, December 1999.

${ }^{18}$ Henry and Dobbs, "Why St. Louis's MetroLink Light Railway is a Mobility Bargain," May 2005. Available on www.lightrailnow.org

${ }^{19}$ Delucchi (1997) is a comprehensive study of the total social cost of motor vehicle use based on 20 reports published by the UC Institute of Transportation Studies, Davis. Delucchi (1996) provides a summary of the 1997 study.

${ }^{20}$ The estimates here are extracted from page 12 of Delucchi (2000). In the actual table provided by Delucchi, there is an estimate of government subsidies for light rail which increases the total external cost of light rail. I ignore this subsidy for light rail since my focus here is to ask the question, Are the positive externalities provided by light rail sufficient to offset the cost disadvantages arising from the high capital cost of the Heartland LRT System?

${ }^{21}$ See Banzhaf and Jawahar (2005) for a comprehensive introduction to this literature. 
${ }^{22}$ The underlying research in both these papers contributed to a provision passed by the Florida legislature in 2005 . The provision encourages local governments to require a full cost accounting analysis for any proposed new development.

${ }^{23}$ See Litman (2007), Table 5.14-13, p. 5.14-21.

${ }^{24}$ U.S. Census Bureau data indicate that the mean travel time to work in Missouri is about 23 minutes. At $40 \mathrm{mph}$, this indicates an average one-way commute of about 15 miles.

${ }^{25}$ This calculation assumes one passenger per car. In addition to these external costs, TRIP estimates that the poor condition of roads in Kansas City imposes an additional operational cost per automobile of $\$ 651$ per year.

${ }^{26}$ Victoria Transport Policy Institute, Transportation Cost and Benefit Analysis, May 2007 (available on www.vtpi.org). See Table 6-6 on pp. 6-10.

${ }^{27}$ In addition to these external costs, TRIP estimates that the poor condition of roads in Kansas City impose an additional operational cost per automobile of $\$ 651$ per year.

${ }^{28}$ See Appendix B of the Central Business Corridor Transit Plan, Final Report.

${ }^{29}$ See Castelazo and Garrett (2004)'s "Light Rail: Boon or Boondogle," which invokes the "give them a Toyota Prius instead" argument. A response to this study is contained in Henry and Dobbs (2005), "Why St. Louis's Metro Link Railway in a Mobility Bargain."

\section{References}

Banzhaf, S., and P. Jawahar. 2005. Public benefits of undeveloped lands on urban outskirts: None market valuation studies and their role in land use plans, Resources for the Future. Available at http://www.biodiversitypartners.org/ econ/assessingwealth/PublicBenefits.pdf

Baum-Snow, N., and M. Kahn. 2005. Effects of urban rail transit expansions: Evidence from sixteen cities, 1970-2000. Brookings-Wharton Papers on Urban Affairs.

Brealey, R., S. Myers, and F. Allen. 2006. Principles of corporate finance. New York: McGraw-Hill Irwin. 
Castelazo, M., and T. Garrett. 2004. Light rail: Boon or boondogle. Regional Economist, Federal Reserve Bank of St. Louis.

Central Business Corridor Transit Plan. April 27, 2001. Final Report.

Delucchi, Mark. 1997. Annualized social cost of motor vehicle use in the U.S. 1990-1991: Summary of theory, methods, data, and results. University of California, Institute of Transportation Studies. UCD-ITS-RR-96-3 (1). Available at www.its.ucdavis.edu,

Delucchi, M. 1996. Total cost of motor vehicle use. Access 8: 7-13.

Delucchi, M. 2000. Should we try to get the prices right? Access 10: 10-14.

Henry, L., and D. Dobbs. 2005. Why St. Louis's Metro Link Railway is a mobility bargain. Available on www.lightrailnow.org.

Kiker, C.F., and A.W. Hodges. 2002. Economic benefits of natural land conservation: Case study of northeast Florida. Final Report. Washington, DC: Defenders of Wildlife.

Kroeger, T. 2005. The economic value of ecosystem services in four counties in northeastern Florida. Washington, DC: Defenders of Wildlife.

Litman, T. 2007. Transportation cost and benefit analysis: Techniques, estimates and implications. Available on www.vtpi.org.

McPhearson, G., D. Nowak, G. Heisler, S. Grimmond, C. Souch, R. Grant, and R. Rowan. 1997. Quantifying urban forest structure, function, and value: The chicago Urban forest climate project. Urban Ecosystems 1: 49-61.

Mid America Regional Council (MARC), Long Range Transportation Outlook Transportation Outlook 2030. Available at http://www.marc.org/outlook2030/

Mid America Regional Council (MARC) (2000/2001). Travel Time Study.

Riddel, M. 2001. A dynamic approach to estimating hedonic prices for environmental goods: An application to open space purchase. Land Economics 77 (4): 494-512.

Road Information Program (TRIP). 2006. Rough ride in the city: Metro areas with the roughest rides and strategies to make our roads smoother.

Road Information Program (TRIP). 2004. Bumpy roads ahead. 
Roe, B., E.G. Irwin, and H.A. Morrow-Jones. 2004. The effects of farmland, farmland preservation, and other neighborhood amenities on housing values and residential growth. Land Economics 80(1): 55-75.

Small, K. 1997. Economics and urban transportation policy in the United States. Regional Science and Urban Economics 27: 671-691.

Small, K., et al. 1999. Valuation of travel time savings and predictability in congested conditions for highway user cost estimation. NCHRP 431, Transportation Research Board.

St. Louis Dispatch. March 22, 2007

Thompson, G., and T. G. Matoff. 2003. Keeping up with the Joneses: Planning for transit in decentralizing regions. Journal of the American Planning Association 69 (3): 296-312.

Toole, R. 2005. Does light rail pay for itself? Available at http://www.ti.org/vaupdate57.html.

U.S. Census Bureau. 2005. Commuting to Work.

Victoria Transport Policy Institute. 2007. Transportation cost and benefit analysis. Available at www.vtpi.org

Vuchic,V. 1999. Transportation for livable cities. Rutgers University: Center for Urban Policy Research.

\section{About the Author}

SUDHAKAR RAJU (sudhakar.raju@rockhurst.edu) is Professor of Finance at Rockhurst University in Kansas City, Missouri. He is a graduate of Harvard University and has served as a consultant to organizations such as the Chicago Board of Trade, the World Bank, and the United Nations. This paper was written while he was at the Kennedy School of Government, Harvard University. 